many cases of swelled-head in college graduates, a matter which interferes with their employment in a good many instances. Reference was also made in the discussion to the plan followed at Bristol, whereby unsuitable students are advised, through their parents, to withdraw from college at the earliest possible moment. (It may be said here that other colleges also follow this procedure.)

Prof. Archibald Barr advocated a six months' sandwich systern, and pleaded that engineering institutions should allow a wide latitude in the systems of training that they will recognise. Prof. Henry Louis did not think that the six months' sandwich system is satisfactory, and suggested the course followed by mining students of three years' college followed by three years' practical work.

Mr. John A. Brodie had little sympathy with those who think it necessary that young engineers should work a reduced number of hours in the workshop in order to enable a greater time being given to study. If the youths of our day cannot or will not stand the strain of the severe training which has given good results in the past, they will probably have to take a position behind those who are prepared to do so. There are other lines of life in which young men can acquire both money and position more easily and quickly than in the engineering profession.

Prof. Stephen M. Dixon opened the subject of the value of a university degree in engineering science in relation to professional competence. There is a feeling in some quarters that the university graduate is rather in the way in an engineer's office. Matters, however, in this respect are improving. When engineering firms recognise the advantage of having assistants thoroughly trained in the principles underlying practice, and whose training also specially fits them for adopting new ideas rapidly, they will be only too glad to cooperate with the universities in completing the education of the engineer.

In dealing with the same subject, Prof. Charles F. Jenkin said that an engineering degree may be looked at in three lights: as a guarantee that the holder has had the best theoretical training and has profited to some extent thereby; as the final step in that type of liberal education at the universities of which England is justly proud; as a broad basis on which State recognition of the engineering profession may be founded.

Prof. Fleming attacked vigorously the whole system of degree examinations as being wrong and as liable to pass candidates whose knowledge was of a very scrappy nature, a view which was promptiv controverted by another speaker, who said that he had five degree men in his London office and was entirely satisfied with the results. The same speaker had a good word to say for men who had been trained in evening classes; he was of opinion that swelled-head accounted for some failures in graduates, but that these men were of use after they had been got in hand.

Profs. Dalby, Hopkinson, and Goodman dealt with the subject of the position and uses of engineering laboratories in relation to education at college. All agree that small units are of more service in the work of education than the very large pieces of apparatus-steam engines of large power and the like-which used to find favour.

In closing the conference, Mr. Alexander Siemens suggested that schoolmasters should try to agree on a common svllabus for leaving examinations. University teaching should be scientific and wide in its scope; the training of the mind is all-essential. He was of opinion that practical training should begin by a vear in the workshops to be followed by the college course, and then back to the workshops again for completion of the practical training.

TOTAL SOLAR ECLIPSE, TASMANIA, MAY, 19 Io. $^{1}$

I $N$ a short introduction the author and leader of the expedition explains his motive in publishing in full this account of a solar eclipse expedition which was, unfortunately, unsuccessful in its main obiect. The site chosen for the camp was in very wild, mountainous

1 Report of the Solar Eclipse Expedition to Port Davey, Tasmania, May, rgro. By F. K. McClean and others. Pp. $42+35$ plates. (London Printed by R. Clay and Sons, Ltd. Plate; reproduced by A. E. Dent and Co., Ltd., 19ro.)

NO. 2 I 75 , VOL. 87$]$ country on the southern shores of Tasmania, and in these circumstances it is evident that, going as a private party, exceptional provision had to be made for the many details of equipment, transportation, and maintenance of the observers during the period of preparation for the observations. It was with the hope of giving useful information on these questions that the author decided to present the $\log$ of his journey at length.

In chapter i. a very interesting account is given of the general preparations for the eclipse, the prospecting journeys for selection of site, that finally occupied being on Hixson Point, Port Davey. After this was settled, some time was occupied in arranging for and purchasing tents, camp equipment, food and drink, and other details necessary for nine persons during a stay of one month. At the camp, nothing was available for food except fish, wallaby, wombats, and kangaroos. A complete list is given of the details of the equipment and stores; in the case of foodstuffs, \&c., both the quantities taken out and the amount unused are given, from which future pioneers in this class of work may learn wisdom; for instance, lime juice was evidently not the beverage most sought after, as out of eighteen bottles taken, thirteen are recorded as unused. A very useful item is the actual cost of the expedition, reckoned from Hobart out to Port Davey, the stay there, and back to Melbourne-347l.

As a more or less detailed account of the instruments taken out for the work on the eclipse has already appeared in Nature, it is only necessary here to say that, in spite of most trying and tempestuous weather, the whole apparatus was adjusted ready for the eclipse time. Details of the work involved for each section are given, with very clear photographic illustrations of the progress and methods adopted in transporting the heavy cases over the difficult ground from the shore to the camp site. Provision had been made for obtaining photographs of the corona with telescopes of various apertures and focal lengths, and for the spectrum of the chromosphere and corona with a powerful concave grating spectrograph.

Included is a report on the observations made by J. Brooks for the determination of the astronomical position of the site, and a description of the corona photographs obtained by another party at Queenstown. After examination of these plates, on which the diameter of the moon's image is $4.4 \mathrm{~mm}$., Mr. W. H. Wesley reports that the extensions of the corona were very small, in no part reaching beyond one quarter the moon's diameter from the limb. On a plate submitted by another observer, with a smaller image still, $1.5 \mathrm{~mm}$., the extensions reach about one diameter. The most striking feature was a wide rift, fairly symmetrical with the South Pole, extending for nearly $50^{\circ}$ along the limb. There was also a long ray of synclinal character on the east of this southern rift.

The form of the corona appears to be of the type associated with the period intermediate between the maximum and minimum of solar activity.

The volume is illustrated by thirty-five excellent photographic reproductions showing the interior of Port Davey Harbour, incidents in the transportation and erection of the various instruments, a scrub fire which very nearly destroyed the camp, and the photographs of the corona obtained at Queenstown by the Rev. L. S. Macdougall and Mr. J. Booton.

Charles P. Butler.

\section{THE CAMBRIDGE ANTHROPOLOGICAL}

\section{EXPEDITION TO WESTERN AUSTRALIA.}

I $\mathrm{N}$ the early part of last year plans were made for an anthropological expedition to Western Australia, and Mr. A. R. Brown, Fellow of Trinity College, Cambridge, who had been re-elected to the Anthony Wilkin studentship, was appointed leader, the main object of the expedition being to study the social organisation and magicoreligious beliefs and observances of the natives. Mr. Brown left England at the end of July, igro. Soon after his arrival in Perth, mainly through the instrumentality of Mrs. D. M. Bates, a donation of Ioool. was made to the expedition by Mr. Samuel P. Mackay of that State. This 
munificent gift is a notable example of public spirit, and it proves that, despite the manifold claims of a very new State on its citizens, there are individuals who have the advancement of pure science at heart. The benefaction was particularly acceptable, as Mr. Brown's modest resources consisted only of the studentship, a gift of $200 \mathrm{l}$. from Sir John Murray, and a grant from the Royal Society of $100 l$. Field investigation is very expensive in Australia, partly owing to the great distances that have to be traversed in order to come into contact with the natives, who even then may be in very small bands.

On his first excursion Mr. Brown was accompanied by Mr. E. L. Grant Watson, of Trinity College, Cambridge, who assisted in taking photographs and measurements of natives, and by Mrs. Bates, who for some years has been employed by the Government of Western Australia to collect information concerning the aborigines of the State. Mrs. Bates has a very considerable knowledge of the natives, and her valuable MS. notes have been placed at Mr. Brown's disposal.

In the south-west corner of the State the natives are extinct; the greater portion of the western half of the State is unopened, and mainly desert country; the natives are quite wild, and it is at present almost impossible to get into touch with them. There remains a broad band of country to the east and the Kimberley gold-field district which have been opened up for pastoral purposes or for gold mining. The gold-field blacks are for the most part beggars, and suspicious and treacherous; they are constantly moving from place to place.

In the eastern part of the region, between the Fortescue and Gascoyne Rivers, there are eleven tribes which belong to one type of social organisation. They never practise circumcision or subincision; they have the usual fourclass system with the kinship system commonly associated therewith, but cross-cousin marriage is prohibited, and there are specific kinship terms to distinguish own mother's brother's children from tribal mother's brother's children. The members of a clan may eat their totem, which is inherited in the male line, and ceremonies of the Intichiuma type are performed for the increase of the totem. Each tribe is divided into definitely circumscribed local groups, the descent of the local group being in the male line. A local group consists mainly, and perhaps in some cases entirely, of persons of the same totem. In most cases the spot at which the ceremonies for the increase of a totem are performed is within the territory of the local group of the men of that totem, but in a few cases a local group contains no totem centre, and the men of the group must journey to some neighbouring group to perform these ceremonies. The totemic sroups are united into larger social divisions, for which $\mathrm{Mr}$. Brown has not yet found a suitable name. During the last two or three generations many irregular marriages have taken place, which have resulted in the distribution of totems through the four classes. In such cases the children take the totem of the father, but enter the class to which they would have belonged if the mother had taken her proper husband. To the south the tribes are, on the whole, very similar to the above; to the east, north-east, and southeast circumcision and subincision are not usually practised; they have the four-class system, and in some tribes every person has several totems (as many as twelve or more), which are inherited in the male line; these may be eaten, and Intichiuma ceremonies are performed. Inland between Fortescue and De Gray Rivers, crosscousin marriage is not permitted, and no distinction is made between own mother's brother's children (and own father's sister's children) and tribal mother's brother's children.

Scattered sporadically all over the area investigated are found the beliefs that children are the result of food eaten, or that they may be projected by magic into a woman. In all cases these beliefs exist side by side with ordinary totemism and entirely independent of it, and also with a perfectly clear recognition of the normal method of procreation.

Mr. Brown is at present on a six months' visit to uninvestigated tribes, mainly in the north-east of the State.

NO. 2 I 75 , vor. 87$]$

A. C. Haddon.
EXPLORATIONS IN DUTCH NEW GUINEA.

$\mathrm{O}^{\mathrm{N}}$ Monday, July 3, Captain C. G. Rawling lectured before the Royal Geographical Society on the geographical results of the British expedition in Dutch New Guinea, which was organised by the British Ornithologists' Union, and was led by Mr. Goodfellow until illness compelled his return. The dense tropical jungle of the low plain between the mountains and the coast, the heavy rainfall, and the sickness which incapacitated their carriers, prevented the travellers from reaching the higher portions of the range, but the scientific results, zoological, ethnographical, and geographical, are most valuable. Captain Rawling and Dr. Marshall stayed for some time with the pygmy tribes of the lower hill ranges, and obtained much information concerning their customs, habits, and general character. Subjoined are some extracts from Captain Rawling's paper.

From inquiries made before leaving England, it was decided that the Oetakwa, the mouth of which river was known to lie due south of Carstenz peak, the greatest of the snow-peaks, should be utilised as our line of communication. Prior to our advent but two rivers on the whole of the south-eastern coast of New Guinea had been visited, the Oetakwa and the Mimika, and these had only been explored for a few miles from their mouth. Further inquiries made in Batavia induced Mr. Goodfellow to change his objective from the Oetakwa to Mimika, and this, little as we suspected it at the time, sealed our fate as to all possibility of ever reaching the Snows.

Almost coal-black in colour, and rather exceeding the average European in height, the Mimika coast native, with his splendidly developed muscles, is physically an almost perfect man. But the brutal features of his face, accentuated by the closely cropped head, makes him anything but an attractive creature. The mass of fuzzy curly hair, in which the natives of other districts take so much pride, is here cut off by means of sharpened shells, split bamboo, or an old piece of hoop iron. What remains is closely plaited in ridges. With the loss of hair nearly all love of decoration or ornament seems to have vanished, their dress consisting of a large white shell worn on the stomach, a hollow carved bamboo, or a narrow strip of tree bark bcaten soft and pliable. Round the neck a few beads may be strung, while below the knees and around the biceps a narrow band of plaited grass may often be seen. As a further attempt at ornament, a few white feathers of the hornbill may be stuck into the hair, or if a fierce expression is desired, the split beak of the same bird is pushed through a hole in the septum nasi. The women are even less given to trinkets, for, besides the narrow strip of bark hanging down in front and behind, they are as bare as nature made them; poor creatures, they have little time to think of anything but work. Widows are rather favoured in this respect, for their weeds consist of a great poke bonnet, in addition to a bodice and skirt, all of grass. The instinct of self-adornment is, however, very strong, for trade articles, such as beads and cloth, were subseauently not only eagerly sought for but worn on all important occasions. Absolute nakedness was rare amongst the Wakatimi people, for girls wore some form of dress from an early age, and boys took on the garb of manhood at the age of fifteen or sixteen.

The front teeth of the men, but not the women, are in many instances sharpened to a point, a painful process, for the operation is carried out, not by filing, but by chipping the sides away with a piece of iron, or, if this is not available, a hard shell used after the manner of a chisel. The custom of sharpening the teeth is often put down as a sign of cannibalistic practices, but we have no reason to believe that the habit of eating human fiesh is ever here nut into practice. Certainly during our sojourn amongst these tribes we saw no signs of cannibalism, nor when cxamining the human bones preserved in every house, did we find any evidence pointing to such a custom. When questioned on this subiect, some natives showed abhorrence. whilst others exhibited, at any rate, no great disgust at the suggestion.

Wakatimi, as we afterwards found, was but a sample of other coast villages, consisting of a long row of huts 